\title{
Specificity protein (Sp) transcription factors and metformin regulate expression of the long non-coding RNA HULC
}

\author{
Shruti U. Gandhy ${ }^{1, *}$, Parisa Imanirad ${ }^{2, *}$, Un-Ho Jin ${ }^{1, *}$, Vijayalekshmi Nair ${ }^{2, *}$, \\ Eric Hedrick ${ }^{2, *}$, Yating Cheng ${ }^{2}$, J. Christopher Corton ${ }^{3}$, KyoungHyun Kim ${ }^{4}$, \\ Stephen Safe ${ }^{1,2}$ \\ ${ }^{1}$ Institute of Biosciences and Technology, Texas A\&M Health Sciences Center, Houston, TX, USA \\ ${ }^{2}$ Department of Veterinary Physiology and Pharmacology, Texas A\&M University, College Station, TX, USA \\ ${ }^{3}$ Integrated Systems Toxicology Division, US-EPA, MD B143-06, Research Triangle Park, NC, USA \\ ${ }^{4}$ Department of Environmental Health, University of Cincinnati, Cincinnati, OH, USA \\ *These authors have contributed equally to this work
}

Correspondence to:

Stephen Safe, e-mail: ssafe@cvm.tamu.edu

Keywords: HCC, Sp proteins, HULC, InCRNAs

Received: May 19, 2015

Accepted: June 23, 2015

Published: July 06, 2015

\section{ABSTRACT}

Specificity protein 1 (Sp1) transcription factor (TF) regulates expression of long non-coding RNAs (IncRNAs) in hepatocellular carcinoma (HCC) cells. RNA interference (RNAi) studies showed that among several IncRNAs expressed in HepG2, SNU-449 and SK-Hep-1 cells, highly upregulated in liver cancer (HULC) was regulated not only by Sp1 but also Sp3 and Sp4 in the three cell lines. Knockdown of Sp transcription factors and HULC by RNAi showed that they play important roles in HCC cell proliferation, survival and migration. The relative contribution of Sp1, Sp3, Sp4 and HULC on these responses in HepG2, SNU-449 and SK-Hep-1 cells were cell context- and response-dependent. In the poorly differentiated SK-Hep-1 cells, knockdown of Sp1 or HULC resulted in genomic and morphological changes, indicating that Sp1 and Sp1-regulated HULC are important for maintaining the mesenchymal phenotype in this cell line. Genomic analysis showed an inverse correlation between expression of genes after knockdown of HULC and expression of those genes in liver tumors from patients. The antidiabetic drug metformin down-regulates Sp proteins in pancreatic cancer, and similar results including decreased HULC expression were observed in HepG2, SNU-449 and SK-Hep-1 cells treated with metformin, indicating that metformin and other antineoplastic agents that target Sp proteins may have clinical applications for HCC chemotherapy.

\section{INTRODUCTION}

Hepatocellular carcinoma (HCC) is one of the leading causes of cancer deaths worldwide and over 500,000 new cases are diagnosed each year [1-3]. The incidence of $\mathrm{HCC}$ is highest in less developed countries where there is widespread hepatitis B virus (HBV) infection. The incidence of HCC in the United States has tripled over the past two decades and this is due, in part, to increased infection with hepatitis $\mathrm{C}$ virus (HCV) $[1,2]$. Treatment for HCC is dependent on tumor stage and can include surgical resection, local ablation by radiofrequency treatment, transarterial chemobolization and radioembolization (TACE) [2] and the mechanism-based receptor tyrosine kinase (RTK) inhibitor sorafenib is also effective for treating patients with advanced HCC [4].

Recent studies show that several long noncoding RNAs (lncRNAs) are overexpressed in HCC and play important functional roles in liver cancer and therefore are also potential drug targets [5-16]. Highly upregulated in liver cancer (HULC) and high expression in HCC (HEIH) are two lncRNAs overexpressed in liver tumors. Both HULC and HEIH play a role in the proliferation of liver cancer cells. HULC is regulated by HBV $\mathrm{X}$ protein (HBX)-dependent activation of CREB which results in downregulation of the tumor suppressor gene $\mathrm{p} 18[7,8]$. The specificity protein $1(\mathrm{Sp} 1)$ 
transcription factor regulates expression of $\mathrm{HEIH}$ in HepG2 and Huh7 cells [16], and genetic network analysis in HCC patients with HBV infection showed that $\mathrm{Sp} 1$ and peroxisome proliferator-activated receptor $\alpha$ regulated pathways are associated with early recurrence of HCC [17].

$\mathrm{Sp} 1, \mathrm{Sp} 3$ and $\mathrm{Sp} 4$ are overexpressed in many different cancer cell lines [18, 19] and high expression of $\mathrm{Sp} 1$ in tumors is a negative prognostic factor for breast, pancreatic, gastric, glioma, prostate and lung cancer patients' survival [20-26]. The relative expression of Sp transcription factors in tumors from HCC patients or in liver cancer cell lines has not been reported; however, there is indirect evidence that $\mathrm{Sp} 1$ and Sp-regulated genes are negative prognostic factors [16, 27, 28]. Several studies show that antineoplastic agents that include non-steroidal anti-inflammatory drugs (including COX-2 inhibitors), metformin, triterpenoids, curcumin and other natural products as well as ROS-inducing agents decreased expression of Sp1, Sp3, Sp4 and pro-oncogenic Sp-regulated genes [18, 29]. In this study, we show that HULC is an Sp-regulated gene and that the functional pro-oncogenic activities of HULC and Sp transcription factors are similar in liver cancer cells. Additionally, we show that HULC and Sp transcription factors are downregulated by the antidiabetic drug metformin.

\section{RESULTS}

\section{Sp1, Sp3 and Sp4 transcription factors regulate HULC and other IncRNAs in HCC cells}

The cell lines used in this study included HepG2 (slow growing, well differentiated), SNU-449 (modestly differentiated), and SK-Hep-1 (poorly differentiated) cells. Fig. 1A shows that Sp1, Sp3 and Sp4 mRNAs were expressed in all three cell lines with the highest levels of Sp1 mRNA in SNU-449 and SK-Hep-1 cells, and Sp3 and Sp4 mRNAs were more highly expressed in SNU-449 cells. Western blot analysis confirmed that Sp1, $\mathrm{Sp} 3$ and Sp4 proteins were also highly expressed in the three HCC cell lines. Using knockdown of Sp1 (siSp1) by RNA interference (RNAi) as a model, we initially investigated the effects of loss of $\mathrm{Sp} 1$ on expression of lncRNAs highly expressed in HCC cells, namely HULC, lncRNA-HEIH, AY129027, DQ786243 and HOTAIR [5] (Fig. 1C). Knockdown of Sp1 downregulated AY12907 in all three cell lines, and lncRNA DQ786243 was increasingly upregulated in the less differentiated cell lines. LncRNA-HEIH and HOTAIR were downregulated upon Sp1 knockdown in SNU-449 and SK-Hep-1 cells but their expression did not change in HepG2 cells. Interestingly, HULC was significantly and consistently downregulated upon Sp1 knockdown in all three HCC cell lines, suggesting that HULC is a Sp-regulated lncRNA in HCC cells.
Regulation of HULC by $\mathrm{Sp} 1, \mathrm{Sp} 3$ and Sp4 in liver cancer cells was investigated by RNAi with oligonucleotides that targeted the individual $\mathrm{Sp}$ transcription factors. HULC expression in the more differentiated HepG2 cell was decreased approximately 20 and $40 \%$ after transfection of siSp1 and siSp3, respectively, but minimal effects were observed in cells transfected with siSp4 (Fig. 2A). In contrast, siSp1, siSp3 and siSp4 significantly decreased expression of HULC ( $>40-70 \%)$ in SNU-449 (Fig. 2B) and SK-Hep-1 (Fig. 2C) cells. Knockdown of Sp1, Sp3 and Sp4 in the HCC cell lines also decreased the protein expression encoded by several prototypical Sp-regulated genes including $B C L-2$, SURVIVIN and EGFR (Suppl. Fig. 1) as previously reported in other cancer cells $[18,29]$. The HULC gene promoter has $\mathrm{GC}$-rich sequences that bind $\mathrm{Sp}$ proteins (Fig. 2D). ChIP analysis showed that Sp1, Sp3 and Sp4 bound the GC-rich region of the HULC promoter in HepG2, SNU-449 and SK-Hep-1 cells and the observed binding was consistent with results showing that $\mathrm{Sp}$ transcription factors regulate HULC expression (Fig. 2C).

\section{Sp proteins and HULC regulate $\mathrm{HCC}$ cell proliferation, survival, migration/invasion}

RNAi was also used to investigate the roles of Sp1, $\mathrm{Sp} 3, \mathrm{Sp} 4$ and HULC in regulating the proliferation and survival of HCC cells. We focused on HULC rather than AY12907 since knockdown of this lncRNA had minimal effects on cell proliferation (data not shown). Transfection of HepG2 (Fig. 3A), SNU-449 (Fig. 3B) and SK-Hep-1 (Fig. 3C) cells with siSp1, siSp3, siSp4 and siHULC inhibited HCC cell proliferation and induced apoptosis (Annexin V staining) and the magnitude of these effects was cell context-dependent. For example, Sp1 and Sp4 knockdown were the most effective inducers of Annexin V in SNU-449 and SK-Hep-1 cells, whereas Sp3 and Sp4 were the most active in HepG2 cells and siHULC induced Annexin $\mathrm{V}$ staining in all 3 cell lines. The percentage of cells with Annexin V staining was greater than 45-80\%, $55-90 \%$ and $70-90 \%$ for HepG2, SNU-449 and SK-Hep-1 cells, respectively.

Using Sp1 knockdown as a model, HCC cells were transfected with siHULC or siSp1 and their effects on transwell migration and invasion of the three liver cancer cell lines were determined (Fig. 4). The results show that transfection of HepG2 (Fig. 4A), SNU-449 (Fig. 4B) and SK-Hep-1 (Fig. 4C) cells with siSp1 or siHULC significantly decreased cell migration in all the cell lines and decreased SNU-449 and SK-Hep-1 cell invasion in a Boyden chamber assay (Fig. 4B and 4C); effects were minimal for HepG2 cells (Fig. 4A) since invasion was not observed for this cell line. Responses observed in cells transfected with siSp1 were higher than siHULC, suggesting more significant contributions from other Spregulated genes. 
A

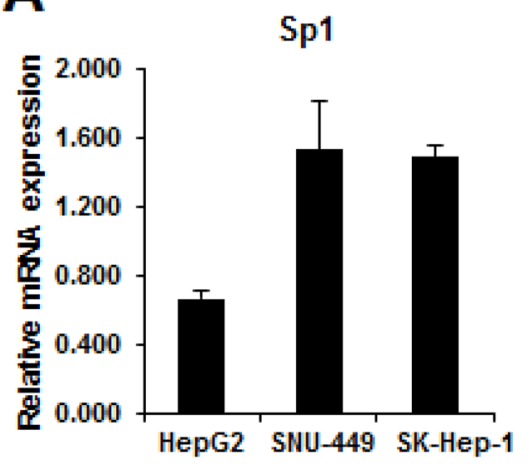

B

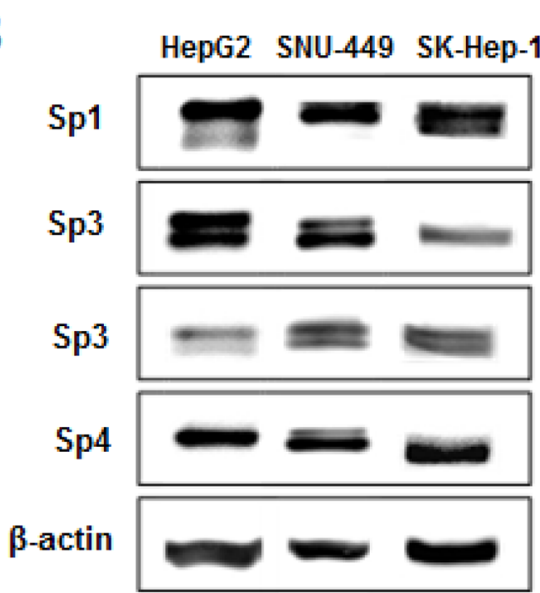

C

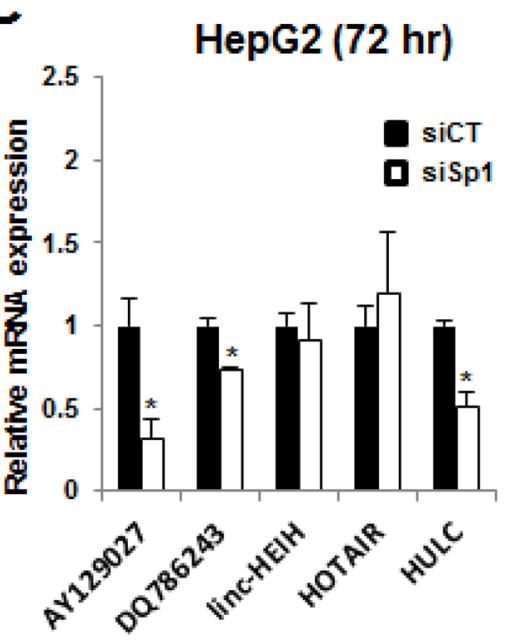

Sp3
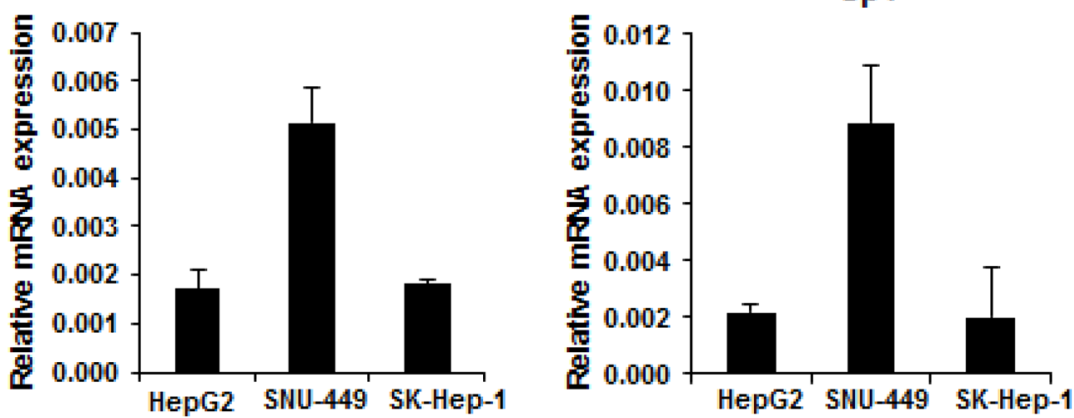
A

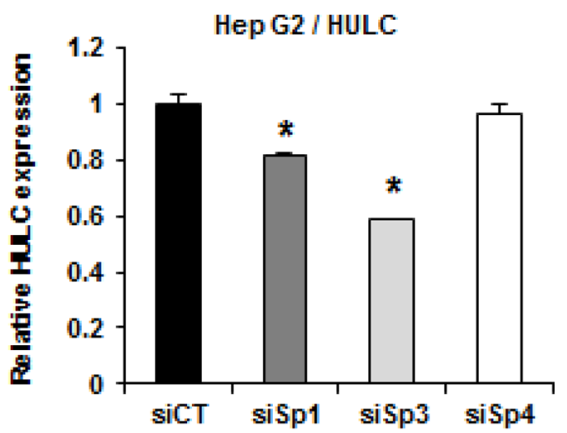

B

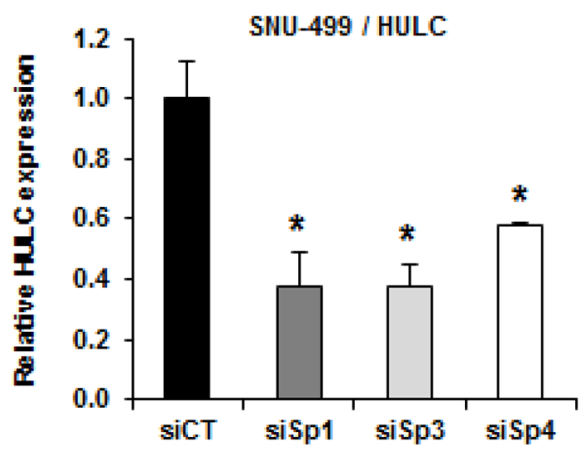

C

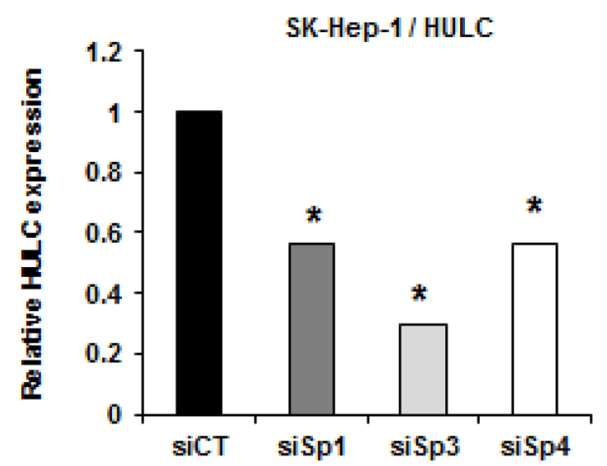

HepG2
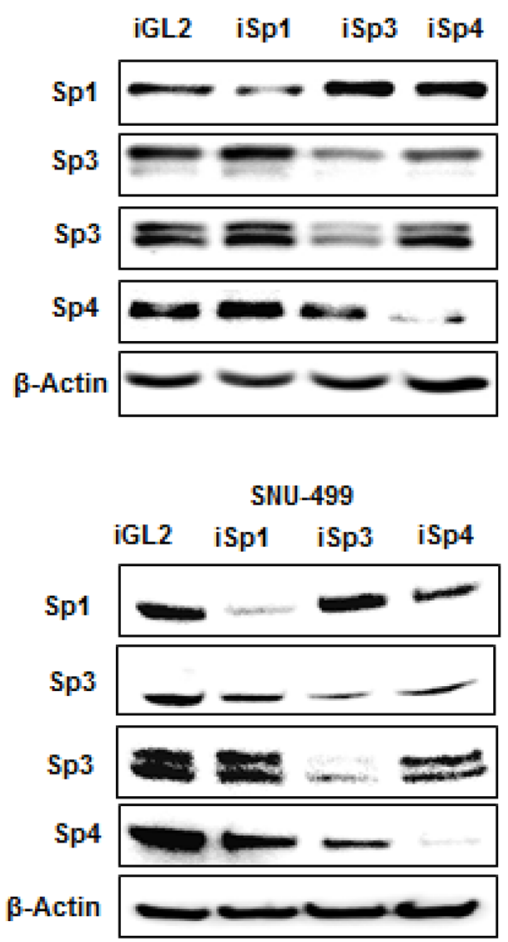

SK-Hep-1

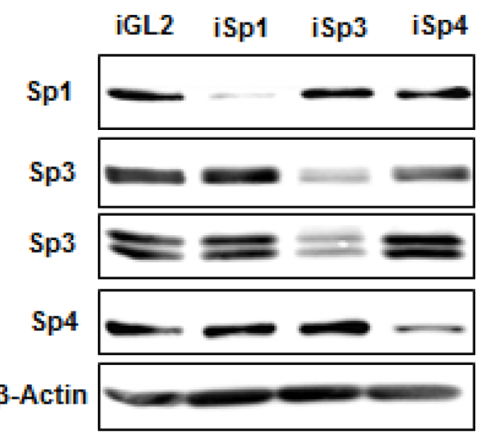

D

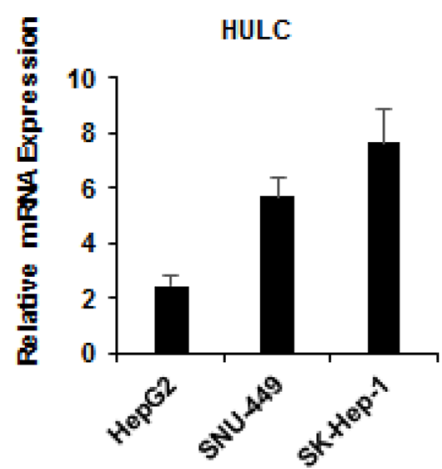

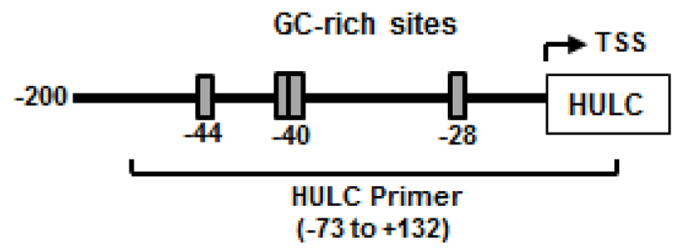

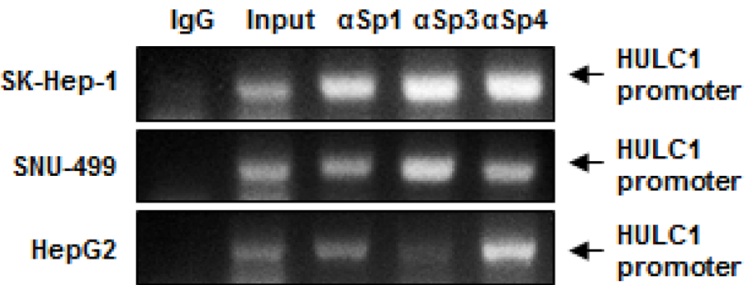

Figure 2: Sp transcription factors regulate HULC expression. HepG2 A. SNU-449 B. and SK-Hep-1 C. cells were transfected with siSp1, siSp3 or siSp4, and HULC and Sp mRNA levels were determined by real time PCR as outlined in the Materials and Methods. Results are means \pm SE for 3 replicate determinations, and significantly $(p<0.05)$ decreased gene expression is indicated $(*)$. D. HULC expression in HCC cells was determined by real time PCR and binding of Sp1, Sp3 and Sp4 to the GC-rich HULC promoter was determined in a ChIP assay as outlined in the Materials and Methods and primers targeted the GC-rich region of the HULC promoter. 
A

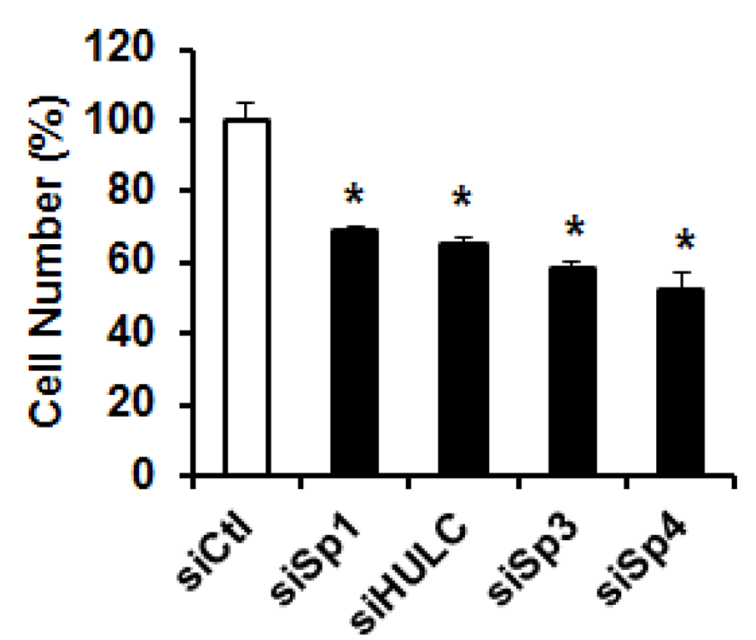

B

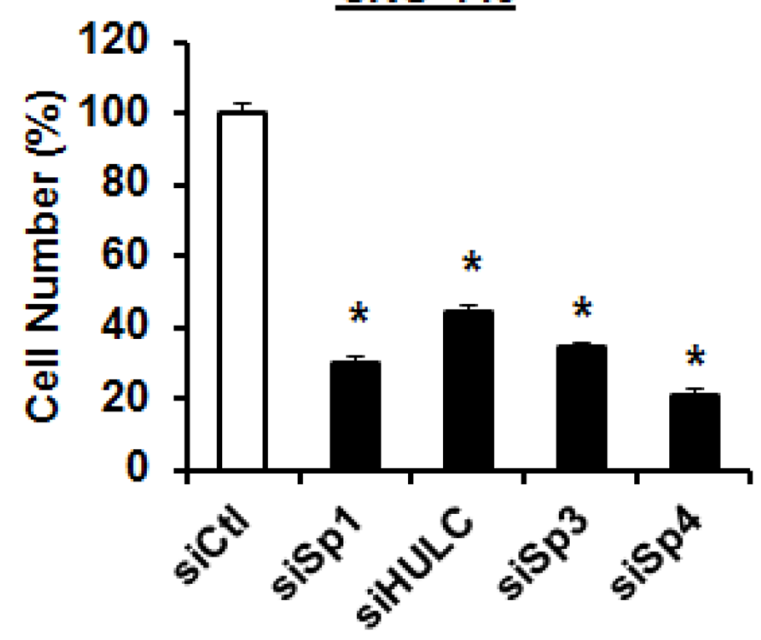

C

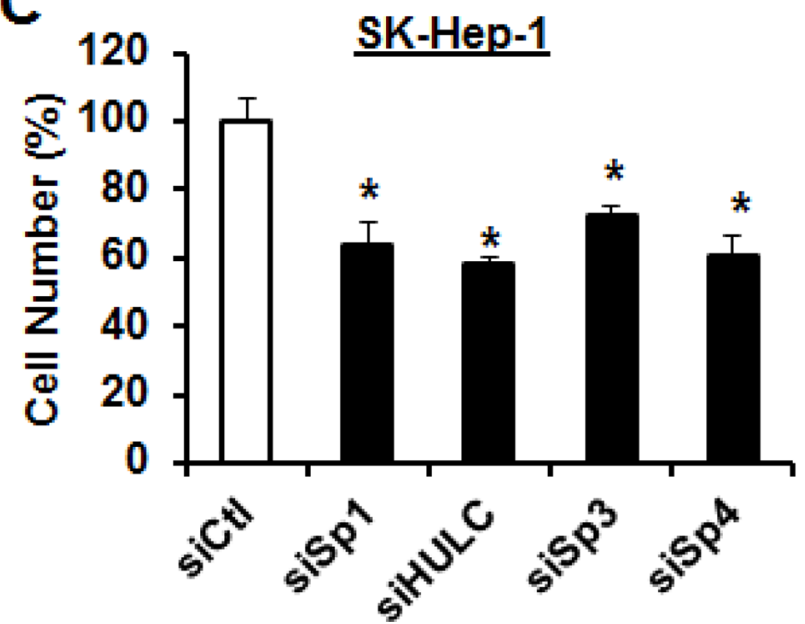

Hep G2

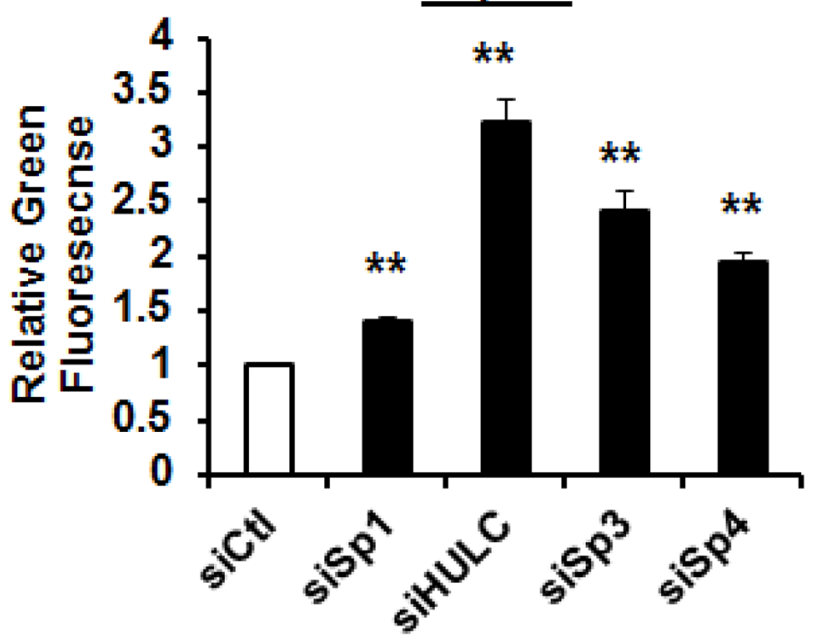

$\underline{\text { SNU-449 }}$

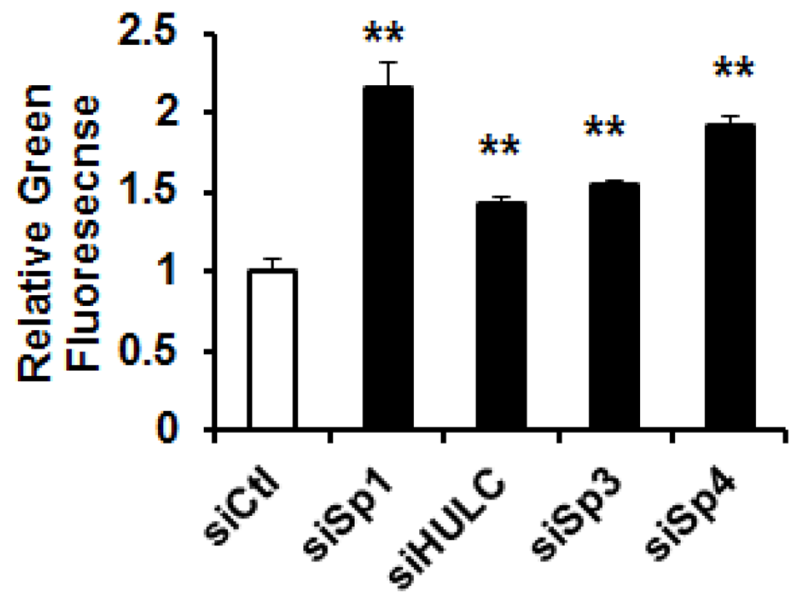

$\underline{\text { SK-Hep-1 }}$

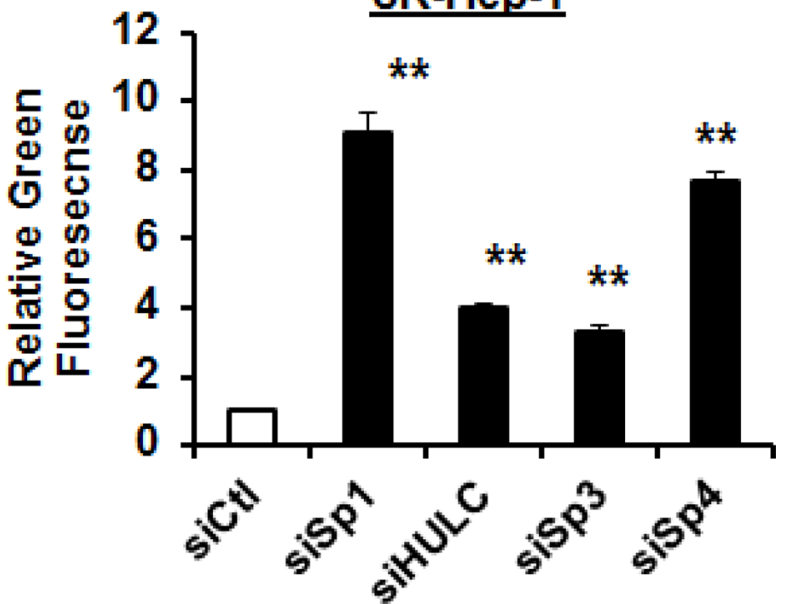

Figure 3: Knockdown of Sp1 and HULC decrease HCC cell proliferation and induce apoptosis. siSp1, siSp3 and siSp4 effects on HepG2 A. SNU-449 B. and SK-Hep-1 C. cell proliferation and induction of Annexin V staining (marker of apoptosis) were determined as outlined in the Materials and Methods. Results are expressed as means \pm SE for at least 3 replicate determinations, and significant $(p<0.05)$ inhibition of cell proliferation $(*)$ or induction of green fluorescent Annexin V staining $(* *)$ are indicated. Transfection efficiencies for knockdown of HULC were $>60 \%$ in all cell lines. 
A
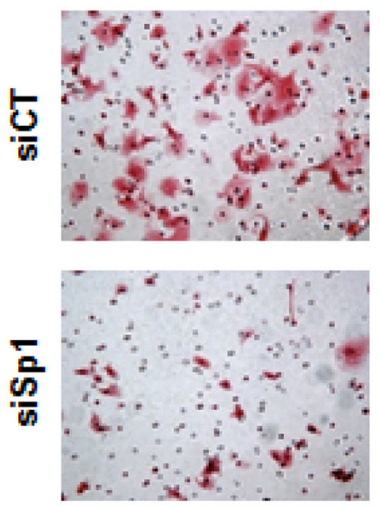

$0.42 \pm 0.11$
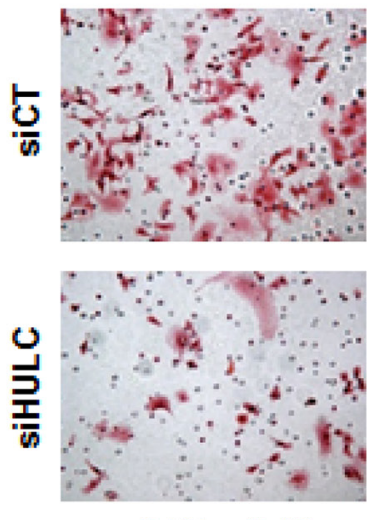

$0.58 \pm 0.16$
B
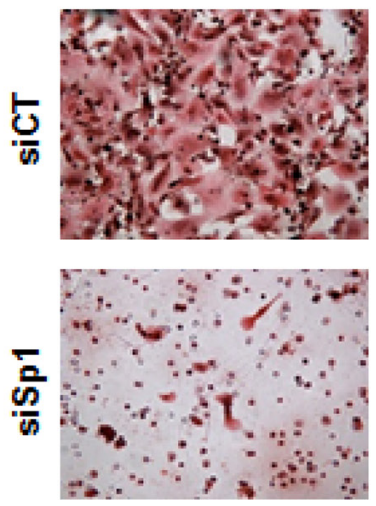

$0.21 \pm 0.06$
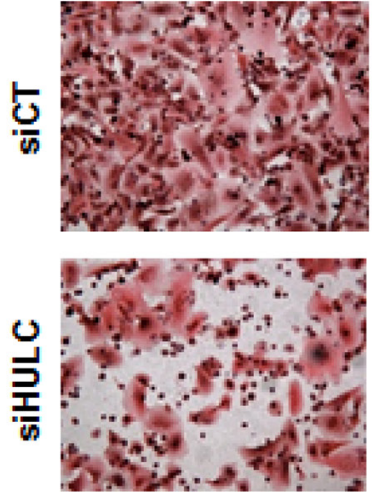

$0.32 \pm 0.10$
SK-Hep-1/Migration

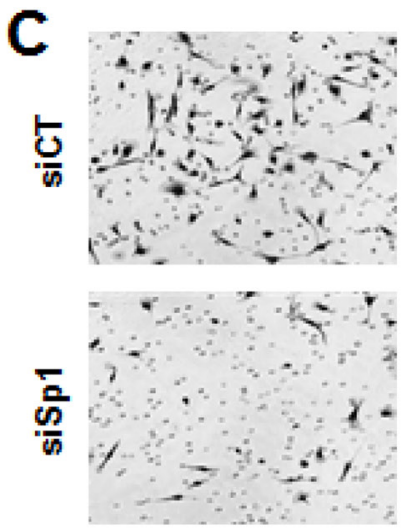

$0.42 \pm 0.11$
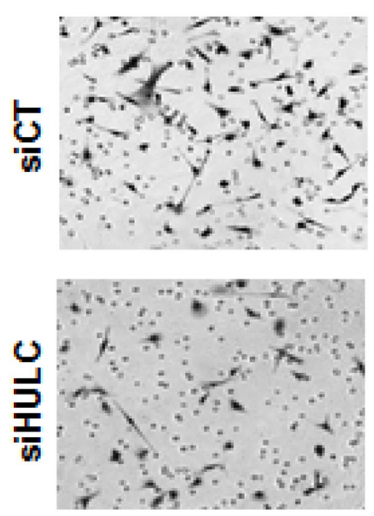

$0.71 \pm 0.18$
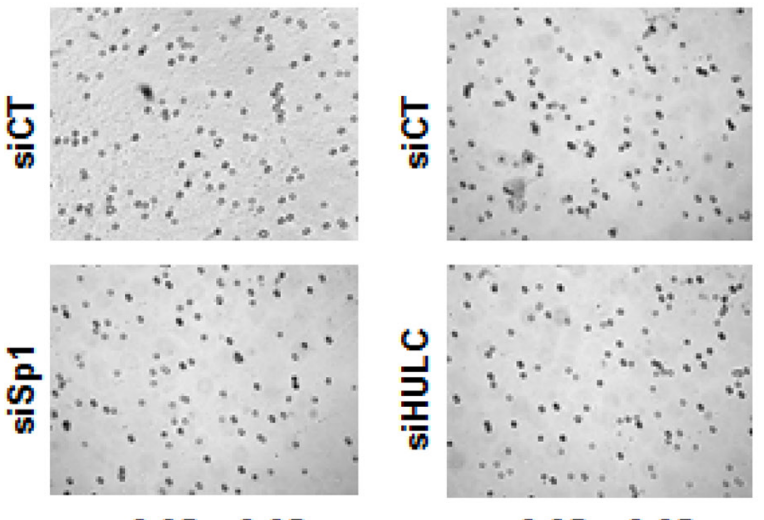

$0.95 \pm 0.05$

$0.95 \pm 0.05$
SNU-449/Invasion
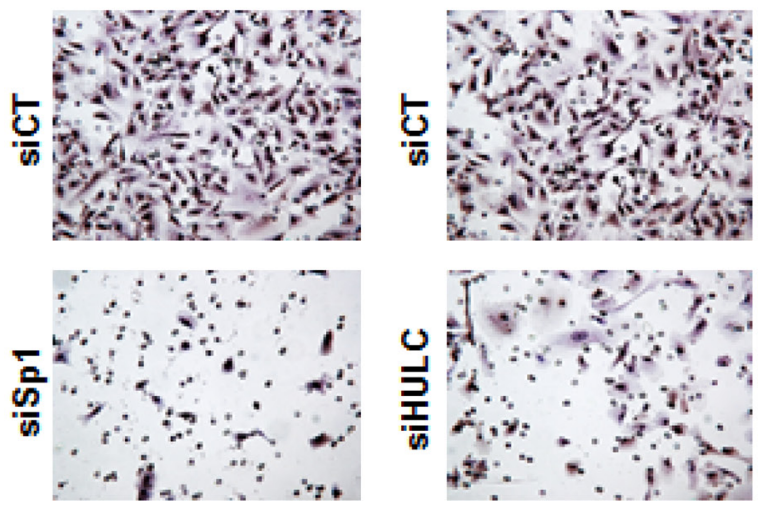

$0.18 \pm 0.11$

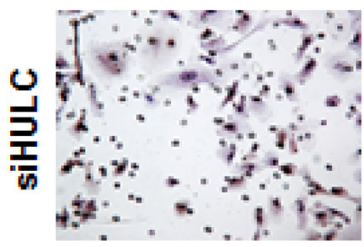

$0.29 \pm 0.09$

\section{SK-Hep-1/Invasion}
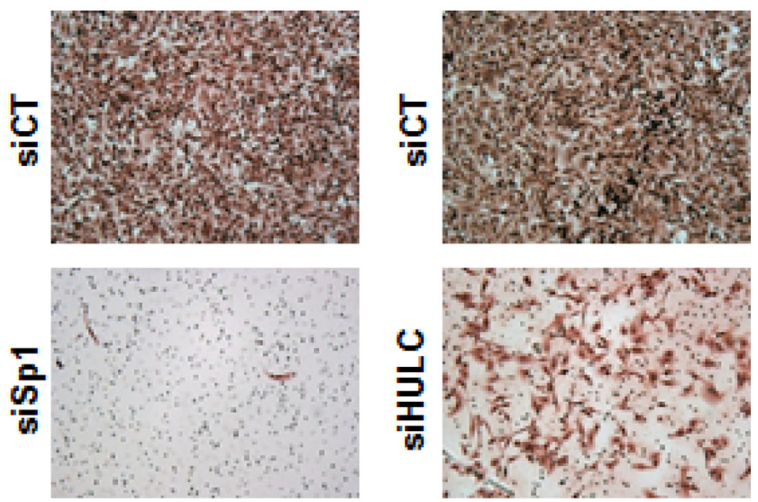

$0.12 \pm 0.11$

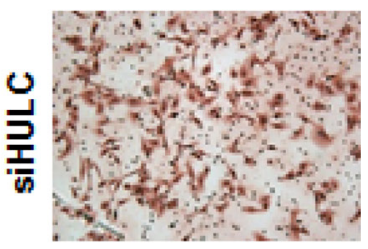

$0.22 \pm 0.15$

Figure 4: Knockdown of Sp1 and HULC inhibit HCC cancer cell migration and invasion. HepG2 A. SNU-449 B. and SK-Hep-1 C. cells were transfected with siCT, siHULC or siSp1, and effects on cancer cell migration and invasion were determined as outlined in the Materials and Methods. Results are means \pm SE for 3 replicate determinations, and values given in the Figures represent the fraction of cells migrating or invading compared to cell transfected with siCT (set at 1.0). 
to mesenchymal transition using the mesenchymal-like SK-Hep-1 cells as a model. Transfection of these cells with siHULC changed cell morphology, slightly increased E-cadherin mRNA and protein, and decreased expression of vimentin mRNA and protein (Fig. 5B-5D). Knockdown of Sp1 in SK-Hep-1 cells also changed cell morphology and had minimal effects on E-cadherin mRNA and protein but significantly decreased vimentin (mRNA and protein) (Fig. 5E-5G). Cell morphology in SK-Hep-1 cells after loss of HULC or Sp1 was more typical of epithelial cells, indicating that Sp1 and HULC played a critical role in maintaining the mesenchymal phenotype.

\section{HULC-regulated gene expression in cells and correlation with genes overexpressed in liver tumors}

Illumina human V.3 HT12 beadchip arrays were used to examine effects of transfection with siHULC on changes in gene expression in SK-Hep-1 cells. HULC knockdown resulted in the increase and decrease of 135 and 215 genes, respectively (Fig. 6A). Gene ontology analysis showed that HULC regulates expression of genes associated with cell growth/cell cycle expression, apoptosis, migration and several other functions. Many lncRNAs interact with chromatin modifying complexes to regulate gene expression and since mixed linkage leukemia 1 (MLL1) and enhancer of zeste homology 2 (EZH2) are both involved in hepatocarcinogenesis $[31,32]$ and also components of chromatin-modifying complexes, we compared the overlap of genes in SK-Hep-1 cells transfected with siHULC with siMLL1 and siEZH2. Fig. 6B illustrates the number of common genes coregulated by HULC/MLL1 and HULC/EZH2 after knockdown experiments (siHULC, siMLL1 and siEZH2) in SK-Hep-1 cells. The overlap in HULC/EZH2 coregulated genes was minimal, whereas HULC/MLL1 coregulated 32 and 57 common genes thatwere down- and upregulated, respectively (Fig. 6B) (Supplemental Table 1). Real time PCR was used in a separate experiment to demonstrate that individual knockdown of siHULC or siMLL1 decreased expression of RRM2, SKP2 and STM1 in SK-Hep-1 cells (Fig. 6C) and this pattern was also observed in the array data (Supplemental Table 2). The TGFBR2 and ITBG1 genes were decreased only by siHULC and this also corresponded to the array data. However, knockdown of MLL1 increased TGFBR2 and ITGB1 gene expression, suggesting that MLL-1 regulation of these genes may be indirect and do not involve coregulation by the MLL-1/HULC complex. Given that knockdown of HULC expression negatively affected the growth and survival of hepatocellular carcinoma cell lines (Fig. 3), we hypothesized that the expression of HULC-regulated genes would negatively correlate with expression of those genes in liver cancer. A total of 350 genes $(\geq 1.5$-fold) regulated by HULC knockdown were compared to the profiles of human liver tumors vs. normal liver in the NextBio database. Out of the total of 56 comparisons, all but three exhibited negative correlation to the HULC-regulated genes, i.e., those genes down-regulated by HULC knockdown were up-regulated in the liver tumors and those genes up-regulated by HULC knockdown were down-regulated in the tumors (Fig. 6D). More than half of these biosets (39 out of 56) exhibited statistically significant negative correlation to the HULC-regulated genes (alpha $=0.05$ with a Benjamini-Hochberg multiple test correction).

\section{Metformin decreases expression of Sp transcription factors and HULC}

The antidiabetic drug metformin [33] decreases expression of Sp1, Sp3, Sp4 and Sp-regulated genes in pancreatic cancer cells [18] and metformin (0-20 mM) inhibited growth of HepG2, SNU-449 and SK-Hep-1 cells after treatment for 24 and $48 \mathrm{hr}$ (Fig. 7A). Metformin also decreased expression of Sp1, Sp3 (high molecular weight), and Sp4 in HepG2 cells after treatment for $24 \mathrm{hr}$; however, the lower molecular weight Sp3 band was not affected, whereas in SNU-449 cells, the higher molecular weight Sp3 band was only slightly decreased (Fig. 7B). In contrast, Sp1, Sp3 (high and low molecular weight), and Sp4 were decreased in the less differentiated SK-Hep-1 cells after treatment with metformin for $24 \mathrm{hr}$ (Fig. 7B) and after treatment for $48 \mathrm{hr}$, all the $\mathrm{Sp}$ transcription factors were decreased in the three cell lines (data not shown). Metformin also decreased expression of HULC in HepG2, SNU-449 and SK-Hep-1 cells (Fig. 7C), demonstrating that drugs targeting Sp transcription factors also target Sp-regulated lncRNAs in HCC cells. Metformin treatment represents a novel mechanistic approach for treating $\mathrm{HCC}$ patients that overexpress Sp transcription factors and HULC.

\section{DISCUSSION}

$\mathrm{Sp}$ transcription factors are overexpressed in multiple tumors and cancer cell lines and there is evidence that $\mathrm{Sp} 1$ is a negative prognostic factor for patients with several different cancers including HCC [20-26]. Sp transcription factors are not only negative prognostic factors for patient survival but also exhibit pro-oncogenic functional activity as determined by knockdown studies in several cancer cell lines $[18,29]$. For example, loss of Sp1 in fibromyosarcomas, gliomas, multiple myeloma, lung, pancreatic and colon cancer cells, and rhabdomyosarcomas results in one or more of inhibition of growth, cell cycle progression, survival, migration and invasion [29, 33-43]. The effects resulting from $\mathrm{Sp} 1$ knockdown are consistent with the parallel decrease in pro-oncogenic Sp-regulated genes associated with cancer cell survival (bcl-2, survivin), proliferation (EGFR, c-MET, cyclin D1), angiogenesis 
A

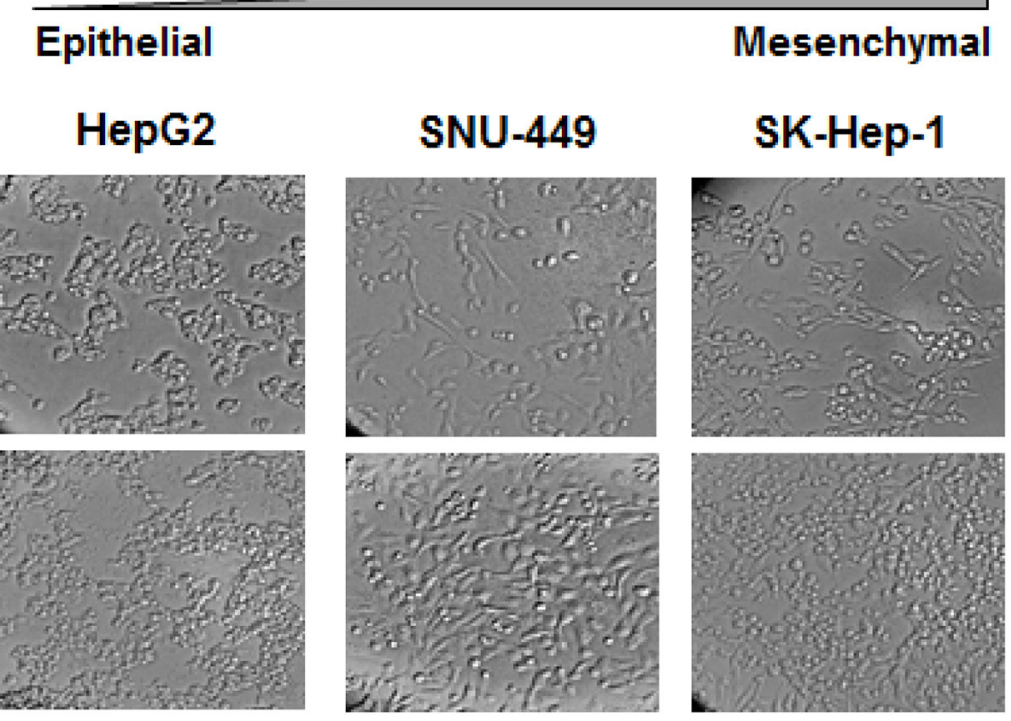

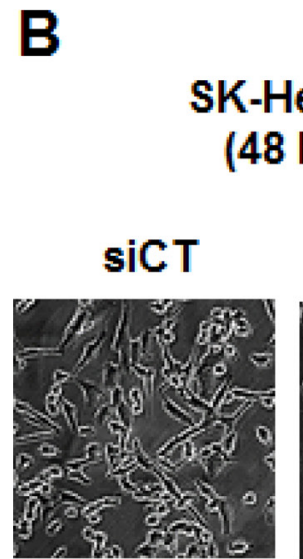

C

\section{SK-Hep-1}

(72 hr)

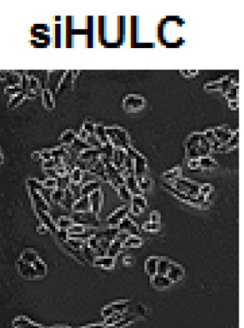

E
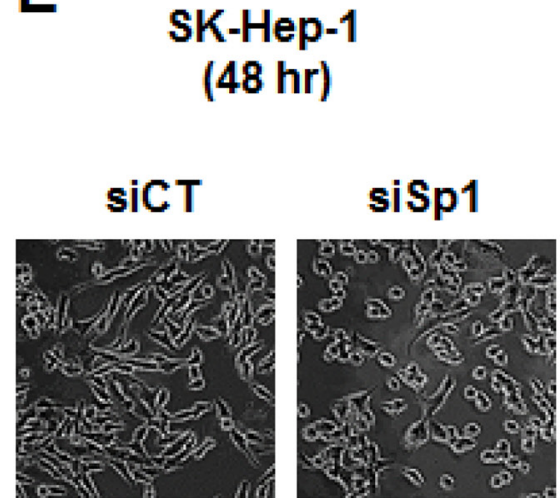

F

SK-Hep-1

(72 hr)
D
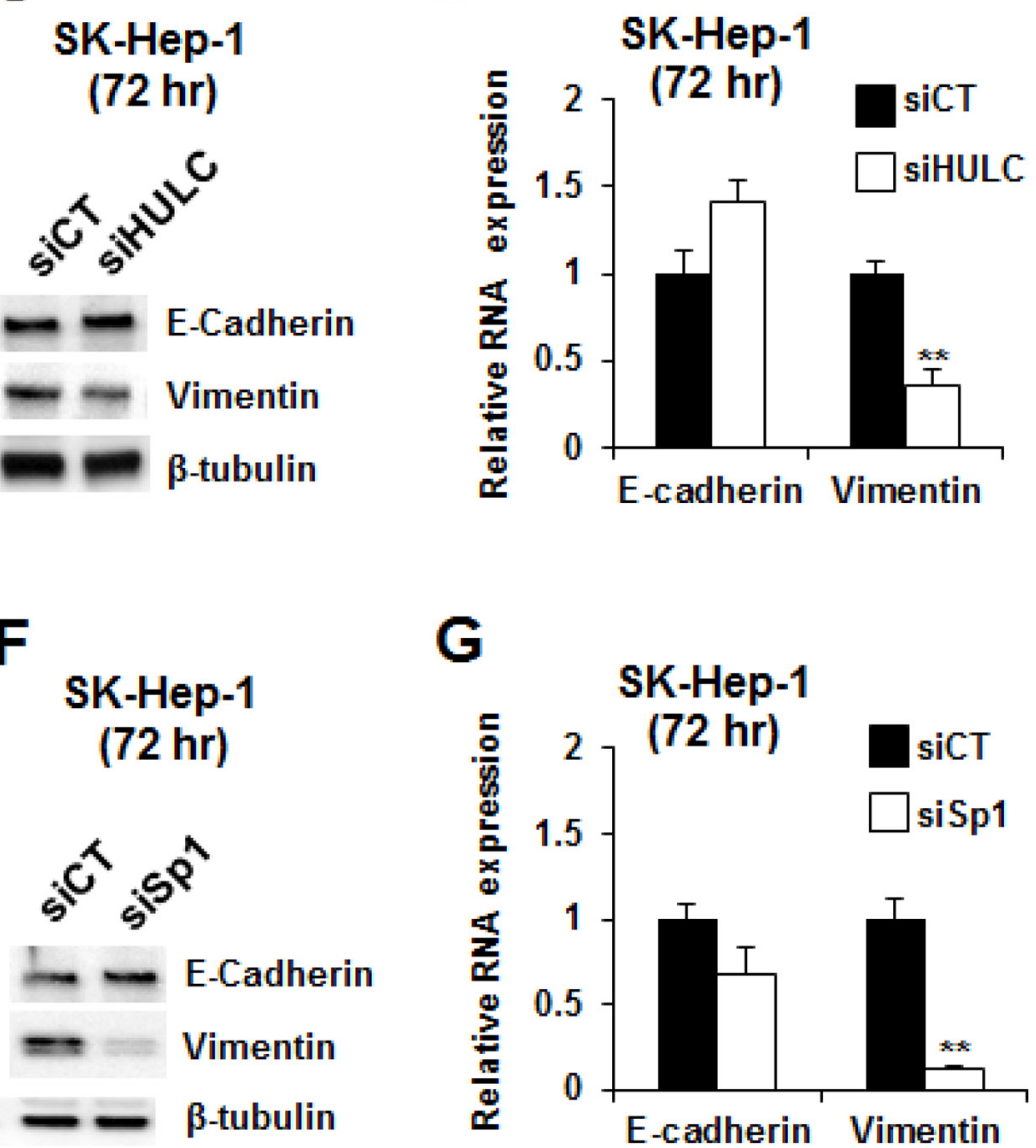

G

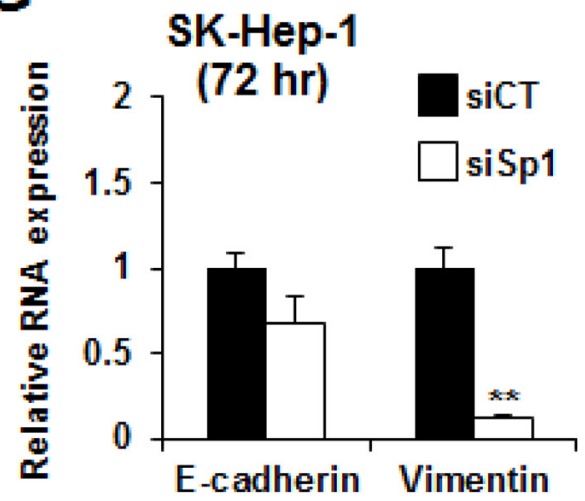

Figure 5: Modulation of epithelial-to-mesenchymal transition by knockdown of Sp1 and HULC. A. The morphology of HepG2, SNU-449 and SK-Hep-1 cells was observed at both low and high confluencies using phase-contrast microscopy (10 $\times$ magnification). SK-Hep-1 cells were transfected with siHULC B-D. and siSp1 E-G. and changes in cell morphology, expression of E-cadherin and vimentin proteins and mRNA were determined by microscopy, western blots and real time PCR, respectively, as outlined in the Materials and Methods. Results (B and C) are expressed as means \pm SE for 3 replicate determinations, and significantly $(p>0.05)$ decreased vimentin expression is indicated $(* *)$. 


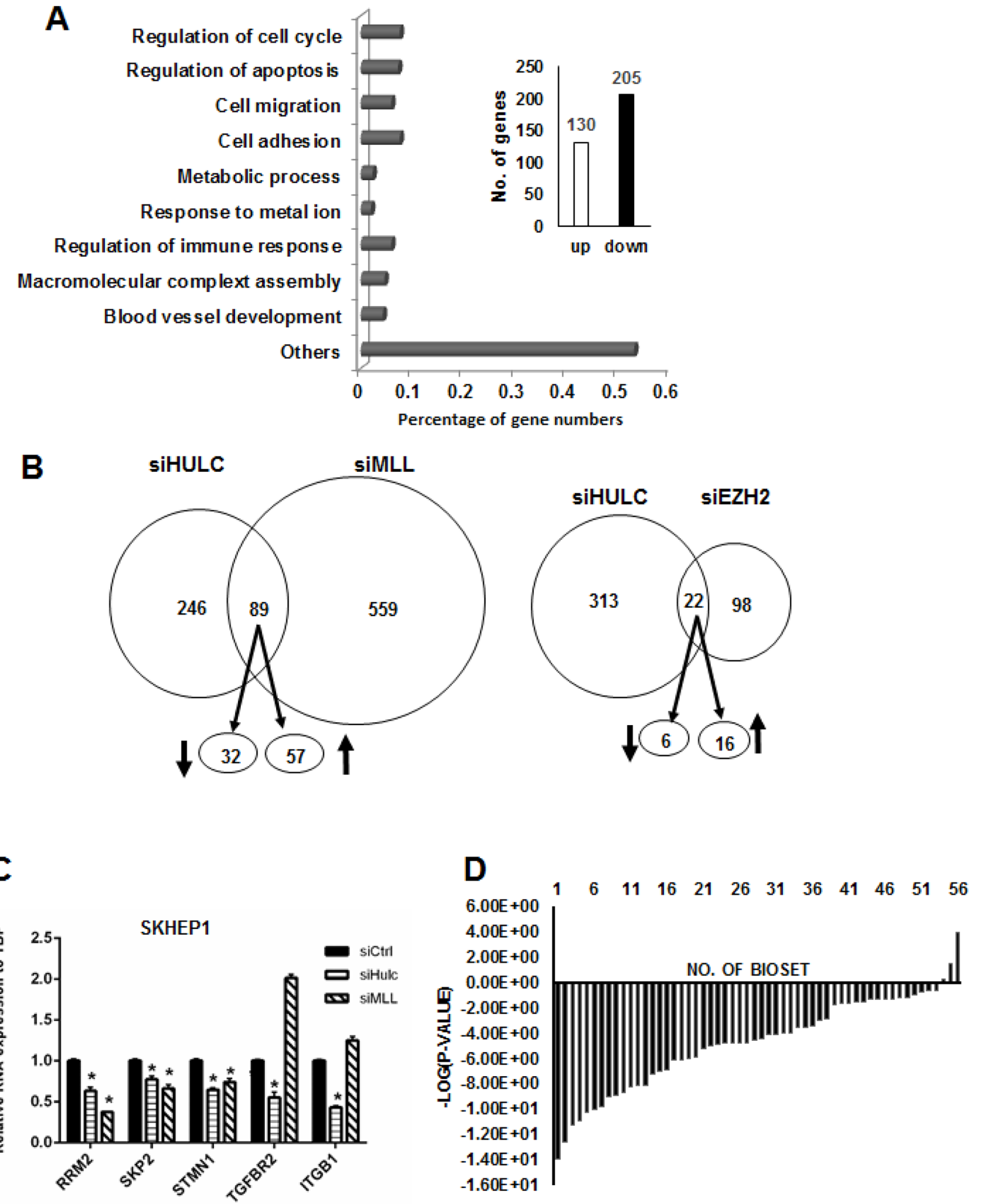

Figure 6: Regulation of genes by HULC and correlation with overexpressed genes in liver tumors. A. Knockdown of HULC by RNAi in SK-Hep-1 cells modulated expression of 350 genes a determined using Illumina human HT12 v4 beadchip arrays and affected multiple cellular functions. B. Overlap of genes in SK-Hep-1 cells after combined knockdown of HULC and LMM1 and HULC and EZH2. C. Confirmation of selected HULC/MLL1 coregulated genes by knockdown and real time PCR. D. Significance of the overlap in the genes after HULC knockdown and in human liver tumors. Comparison between the HULC-regulated genes with genes altered in liver tumors vs. non-tumor tissues (56 biosets) was made using the Running Fishers test in NextBio. 


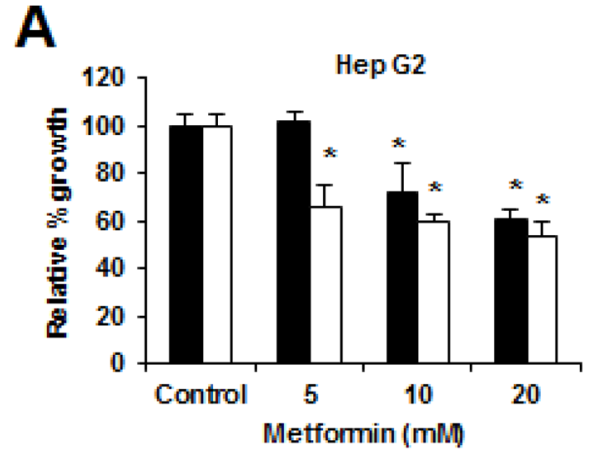

B

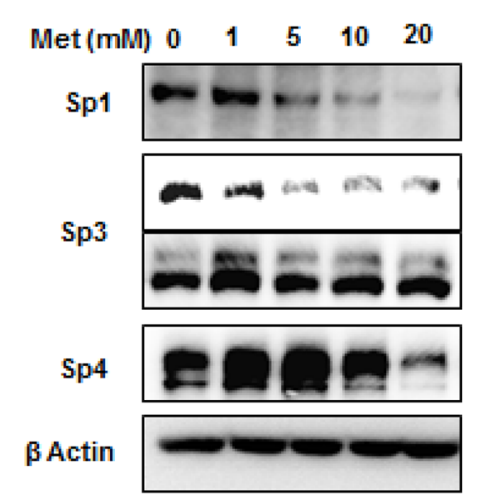

C

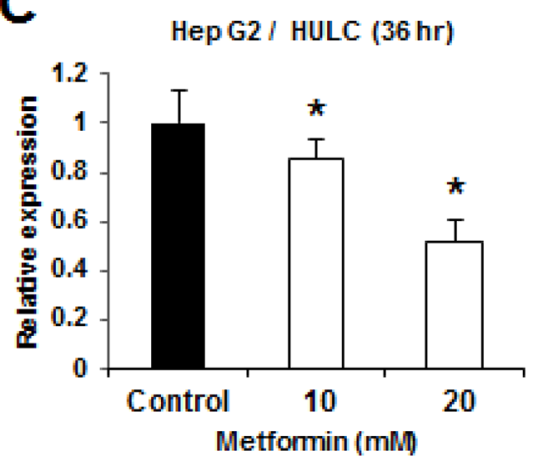

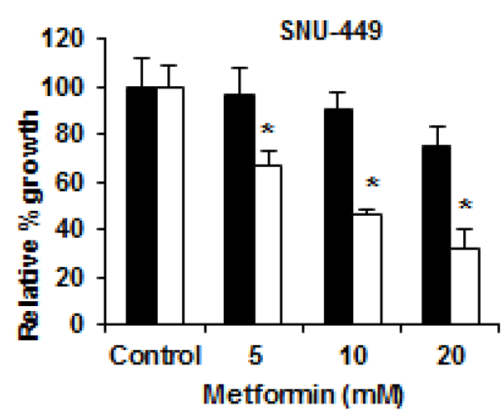

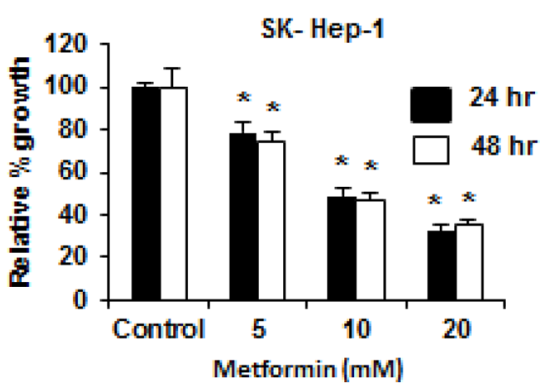

SNU-449
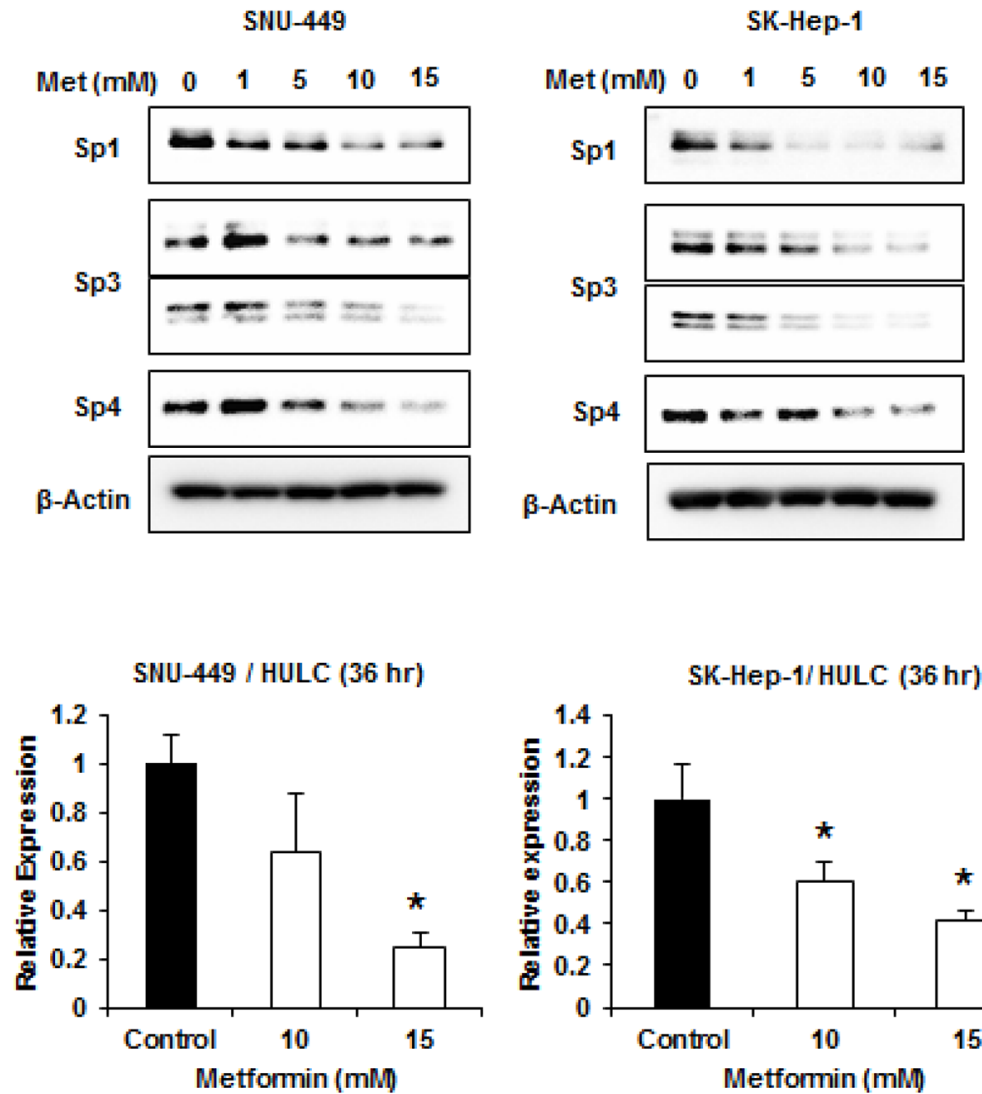

Figure 7: Metformin decreases growth, Sp proteins and HULC expression in HCC cells. HCC cells were treated with DMSO (control) and 1-20 $\mu \mathrm{M}$ metformin for the indicated times, and effects on cell proliferation A. and expression of Sp1, Sp3 and Sp4 proteins B. were determined by cell counting and western blots, respectively, as outlined in the Materials and Methods. C. HCC cells were treated with DMSO, 10 or $15 \mathrm{mM}$ metformin for 36 hours and expression of HULC (relative to DMSO treatment) was determined by real time PCR as outlined in the Materials and Methods. Results (A and C) are expressed as means \pm SE for 3 replicate determinations and significantly $(p<0.05)$ decreased responses are indicated $(*)$.

(VEGF and VEGFR1), inflammation (p65NFkB), and invasion (CXCR4 and MMP9) [18]. Sp3 and Sp4 regulate many of the same functions and genes described for $\mathrm{Sp} 1$; however, the role of Sp1, Sp3 and Sp4 are both gene- and cell context-specific.

In this study, we show that Sp1, Sp3 and Sp4 mRNA and protein are highly expressed in HepG2, SK-Hep-1 and SNU-449 HCC cell lines (Fig. 1A and 1B). It was previously reported that expression of lncRNA-HEIH was decreased after knockdown of Sp1 by RNAi in HepG2 and Huh7 cells [16] and therefore, we initially used RNAi to investigate the role of $\mathrm{Sp} 1$ in regulating a panel of lncRNAs identified in HCC cell lines. Surprisingly, we did not observe decreased expression of IncRNA-HEIH as previously reported [16] and this may be due to a temporal effect which is currently being investigated. Decreased expression of Sp1 differentially modulated expression of the lncRNAs in HepG2, SNU-449 and SK-Hep-1 cells and HULC was one of only two lncRNAs that were Sp1-regulated in all 
three cell lines (Fig. 1C). Moreover, we also observed that knockdown of Sp1 and Sp3 decreased HULC expression in HepG2, SNU-449 and SK-Hep-1 cells and siSp4 decreased HULC in the latter two cell lines (Fig. 2). Sp1, $\mathrm{Sp} 3$ and Sp4 also interacted with the GC-rich HULC promoter in HepG2, SNU-449 and SK-Hep-1 cells (Fig. 2D), further demonstrating a role for Sp transcription factors in regulating this lncRNA. Previous studies showed that PKA and CREB upregulate HULC expression and that insulin-like growth factor mRNA binding protein 1 (IGF2BP1) destabilizes HULC [9], whereas our results demonstrate that $\mathrm{Sp}$ transcription factors are important for basal expression of HULC in HCC cells.

$\mathrm{Sp}$ transcription factors play a role in the proliferation, survival, migration/invasion of several cancer cell lines [18] and we used RNAi to investigate the differential effects of Sp1, Sp3, Sp4 and HULC knockdown on HCC cell proliferation and survival. Loss of the transcription factors and HULC individually decreased cell proliferation and induced apoptosis in all three cell lines and SNU-449 and SK-Hep-1 cells were more sensitive than the more highly differentiated HepG2 cells. Knockdown of Sp1 and HULC also decreased migration and invasion of HCC cells (Fig. 4) and partially reversed the mesenchymal phenotype of SK-Hep-1 cells in which the mesenchymal marker vimentin was decreased (Fig. 5). We also further characterized the role of HULC in liver cancer by examining the modulation of gene expression after knockdown of HULC or knockdown of two important components of chromatin-modifying complexes (MLL1 and EZH2) (Fig. 6). Analysis of array data demonstrated the multifunctional roles of HULC which correlated with the functional effects of knockdown of HULC. Coregulation of genes by HULC and EZH2 or HULC and MLL1 was limited (Fig. 6C); however, there was significant negative correlation between HULC-regulated genes in SK-Hep-1 cells with genes regulated in hepatocellular carcinomas (Fig. 6D). Currently, we are further investigating diagnostic genes overexpressed in tumors and their coregulation by HULC and Sp transcription factors and other chromatin modifying complexes.

Results of this study demonstrate the importance of HULC and Sp transcription factors in HCC, suggesting that both HULC and Sp1 can be targeted by anticancer agents that are known to downregulate Sp transcription factors in other cancer cell lines and tumors [18, 35-40, 43]. Metformin is an antidiabetic drug that protects patients against pancreatic cancer and metformin downregulates $\mathrm{Sp} 1, \mathrm{Sp} 3, \mathrm{Sp} 4$ and prooncogenic Sp-regulated genes in pancreatic cancer cells and tumors [33]. Metformin also protects diabetic patients from development of $\mathrm{HCC}$, and metformin regulated genes/pathways in HCC cell lines are similar to those reported in pancreatic and other cancer cell lines [44-47]. In this study, we show that metformin inhibits growth of HepG2, SNU-449 and SK-Hep-1 cells, and the growth inhibition is accompanied by downregulation of $\mathrm{Sp}$ transcription factors and Sp-regulated HULC expression (Fig. 7). Thus, the antineoplastic effects of metformin are due, in part, to downregulation of Sp proteins and HULC and we are currently investigating other Sp-regulated pathways in HCC cells that contribute to this response.

In summary, this study demonstrates that $\mathrm{Sp} 1$ and other $\mathrm{Sp}$ transcription factors are important for liver cancer cell growth, migration, survival, invasion and epithelial-mesenchymal-transition, and we demonstrate that HULC and other IncRNAs are Sp-regulated genes in HCC. Thus, drugs such as metformin that downregulate Sp transcription factors and Sp-regulated genes (e.g. HULC) may be clinically useful in drug combinations for treating HCC patients that overexpress Sp transcription factors. Moreover, serum levels of HULC $[6,10]$ may be a marker of treatment efficacy.

\section{MATERIALS AND METHODS}

\section{Cell culture, reagents, and antibodies}

HepG2, SNU-449, and SK-Hep-1 cells were obtained from American Type Culture Collection (Manassas, VA). Cells were cultured in Dulbecco's modified Eagle's Medium (DMEM) with High Glucose supplemented with $10 \%$ fetal bovine serum (FBS), $10 \mathrm{~mL} / \mathrm{L}$ of $100 \times$ antibiotic/antimycotic solution (Sigma-Aldrich Co., St. Louis, MO). Cells were grown in $150-\mathrm{cm}^{2}$ culture plates in an air/ $\mathrm{CO}_{2}(95: 5)$ atmosphere at $37^{\circ} \mathrm{C}$. Antibodies were purchased as follows: Sp1, Sp3 and Sp4 (Millipore, Billerica, MA); E-cadherin (Cell Signaling Technology, Danvers, MA), vimentin (Sigma-Aldrich), $\beta$-tubulin (Santa Cruz Biotechnology, Santa Cruz, CA).

\section{Small interfering RNAs and transfection}

Small interfering RNAs (siRNAs) targeting human HULC RNA (siHULC), Sp1 (siSp1), Sp3 (siSp3), and Sp4 (siSp4) were purchased from Sigma-Aldrich. Negative and Positive (Cell Death) Control siRNA were purchased from Qiagen. Transfection was carried out using Lipofectamine RNAiMAX (Invitrogen) according to manufacturer's protocol.

\section{Cell proliferation assay and annexin $\mathrm{V}$ staining}

Cell proliferation and Annexin V staining was carried as previously described [29]. For knockdown experiments with siRNAs, effects of cell proliferation and Annexin V staining were determined after $72 \mathrm{hr}$.

\section{Quantitative real time PCR (qRT-PCR) and western blot analysis}

Total RNA was isolated and analyzed by qRT-PCR as described [29]. Primers were purchased from Integrated 
DNA Technologies and the primers are summarized in Supplemental Table 2. Western blot analysis of whole cell lysates was determined as previously described [29].

\section{Transwell migration and invasion and chromatin immunoprecipitation (ChIP) assays}

Migration and invasion assays were performed using 24-well transwell chamber with $8 \mu \mathrm{M}$ pore size polycarbonate membrane (Corning Costar), and invasion assays were carried out under the same conditions with the exception of the transwell chamber used as described [29]. The ChIP assay was performed using ChIP-IT Express Magnetic Chromatin Immunoprecipitation kit (Active Motif, Carlsbad, CA) according to the manufacturer's protocol essentially as described [29].

\section{Gene analysis}

Total RNA was extracted from Panc1 cells by using mirVana $^{\mathrm{TM}}$ miRNA Isolation Labeling Kit (Ambion, Inc./LifeTechnologies, Grand Island, NY) and quantified by using Nanodrop ND-1000 spectrophotometer (NanoDrop Technology, Wilmington, DE). HumanHT-12 v4 expression beadchip arrays (Illumina, Inc., San Diego, CA) were used for determining changes in gene expression according to the manufacturer's protocol and microarray data were normalized using the quantile normalization method in the Linear Models for Microarray Data (LIMMA) package in the R language (http://www.r-project.org). Differentially expressed genes were identified using $a>1.5$-fold change cut off. Gene ontology enrichment analysis was carried out using David Functional Annotation Resources 6.7 (http://david. abcc.ncifcrf.gov/). A rank-based nonparametric analysis strategy called the Running Fisher's algorithm and implemented within the NextBio database (http://www. nextbio.com/) environment was used to identify gene expression comparisons (biosets) which have statistically significant positive or negative correlation to the genes regulated by siHULC in SK-Hep-1 cells. The Running Fisher's algorithm computes statistical significance of similarity between ranked fold-change values of two gene lists [48]. After exporting the analysis, the list of correlated biosets were filtered to identify those that examined gene expression changes in liver tumors.

\section{Statistical analysis}

Statistical significance of differences between the treatment groups was determined using the Student's $t$ test, and levels of probability were noted.

\section{ACKNOWLEDGMENTS}

The advice and assistance of Dr. Ping Lei and Dr. Syng-Ook Lee was appreciated.

\section{CONFLICTS OF INTEREST}

There are no conflicts of interest to declare.

\section{FINANCIAL SUPPORT}

National Institutes of Health (P30-ES023512) and Texas AgriLife.

\section{Abbreviations}

ChIP, chromatin immunoprecipitation; DMEM, Dulbecco's modified Eagle's medium; FBS, fetal bovine serum; HBV, hepatitis B virus; HBX, HBV X protein; HCC, hepatocellular carcinoma; HULC, highly upregulated in liver cancer; IGFBP1, insulin-like growth factor binding protein 1; IncRNA, long non-coding RNA; NSAIDs, non-steroidal anti-inflammatory drugs; PVDF, polyvinylidene difluoride membrane; qRT-PCR, quantitative real time PCR; RNAi, RNA interference; RTK, receptor tyrosine kinase; siRNA, small inhibitory RNA; Sp1, specificity protein 1; TACE, transarterial chemobolization and radioembolization; TBP, TATA binding protein; TBST, Tris-buffered saline with Tween; VEGF, vascular endothelial growth factor; VEGFR, vascular endothelial growth factor receptor

\section{REFERENCES}

1. Ferlay J, Bray F, Pisani P, Parkin DM. (2001). GLOBOCAN 2000: cancer incidence, mortality adn prevalence worldwide, version 1.0. (Lyon, France: International Agency for Research on Cancer).

2. El-Serag HB. Hepatocellular carcinoma. The New England journal of medicine. 2011; 365:1118-1127.

3. Siegel R, Ma J, Zou Z, Jemal A. Cancer statistics, 2014. CA: a cancer journal for clinicians. 2014; 64:9-29.

4. Llovet JM, Ricci S, Mazzaferro V, Hilgard P, Gane E, Blanc JF, de Oliveira AC, Santoro A, Raoul JL, Forner A, Schwartz M, Porta C, Zeuzem S, Bolondi L, Greten TF, Galle PR, et al. Sorafenib in advanced hepatocellular carcinoma. The New England journal of medicine. 2008; 359:378-390.

5. Huang JL, Zheng L, Hu YW, Wang Q. Characteristics of long non-coding RNA and its relation to hepatocellular carcinoma. Carcinogenesis. 2014; 35:507-514.

6. Panzitt K, Tschernatsch MM, Guelly C, Moustafa T, Stradner M, Strohmaier HM, Buck CR, Denk H, Schroeder R, Trauner M, Zatloukal K. Characterization of HULC, a novel gene with striking up-regulation in hepatocellular carcinoma, as noncoding RNA. Gastroenterology. 2007; 132:330-342.

7. Wang J, Liu X, Wu H, Ni P, Gu Z, Qiao Y, Chen N, Sun F, Fan Q. CREB up-regulates long non-coding RNA, HULC 
expression through interaction with microRNA-372 in liver cancer. Nucleic acids research. 2010; 38:5366-5383.

8. Du Y, Kong G, You X, Zhang S, Zhang T, Gao Y, Ye L, Zhang X. Elevation of highly up-regulated in liver cancer (HULC) by hepatitis B virus X protein promotes hepatoma cell proliferation via down-regulating $\mathrm{p} 18$. The Journal of biological chemistry. 2012; 287:26302-26311.

9. Hammerle M, Gutschner T, Uckelmann H, Ozgur S, Fiskin E, Gross M, Skawran B, Geffers R, Longerich T, Breuhahn K, Schirmacher P, Stoecklin G, Diederichs S. Posttranscriptional destabilization of the liver-specific long noncoding RNA HULC by the IGF2 mRNA-binding protein 1 (IGF2BP1). Hepatology. 2013; 58:1703-1712.

10. Xie H, Ma H, Zhou D. Plasma HULC as a promising novel biomarker for the detection of hepatocellular carcinoma. BioMed research international. 2013; 2013:136106.

11. Liu Y, Pan S, Liu L, Zhai X, Liu J, Wen J, Zhang Y, Chen J, Shen H, Hu Z. A genetic variant in long non-coding RNA HULC contributes to risk of HBV-related hepatocellular carcinoma in a Chinese population. PloS one. 2012; 7:e35145.

12. Tsang WP, Kwok TT. Riboregulator H19 induction of MDR1-associated drug resistance in human hepatocellular carcinoma cells. Oncogene. 2007; 26:4877-4881.

13. Yang Z, Zhou L, Wu LM, Lai MC, Xie HY, Zhang F, Zheng SS. Overexpression of long non-coding RNA HOTAIR predicts tumor recurrence in hepatocellular carcinoma patients following liver transplantation. Annals of surgical oncology. 2011; 18:1243-1250.

14. Yuan SX, Yang F, Yang Y, Tao QF, Zhang J, Huang G, Yang Y, Wang RY, Yang S, Huo XS, Zhang L, Wang F, Sun SH, Zhou WP. Long noncoding RNA associated with microvascular invasion in hepatocellular carcinoma promotes angiogenesis and serves as a predictor for hepatocellular carcinoma patients' poor recurrence-free survival after hepatectomy. Hepatology. 2012; 56:2231-2241.

15. Geng YJ, Xie SL, Li Q, Ma J, Wang GY. Large intervening non-coding RNA HOTAIR is associated with hepatocellular carcinoma progression. The Journal of international medical research. 2011; 39:2119-2128.

16. Yang F, Zhang L, Huo XS, Yuan JH, Xu D, Yuan SX, Zhu N, Zhou WP, Yang GS, Wang YZ, Shang JL, Gao CF, Zhang FR, Wang F, Sun SH. Long noncoding RNA high expression in hepatocellular carcinoma facilitates tumor growth through enhancer of zeste homolog 2 in humans. Hepatology. 2011; 54:1679-1689.

17. Woo HG, Park ES, Cheon JH, Kim JH, Lee JS, Park BJ, Kim W, Park SC, Chung YJ, Kim BG, Yoon JH, Lee HS, Kim CY, Yi NJ, Suh KS, Lee KU, et al. Gene expression-based recurrence prediction of hepatitis $\mathrm{B}$ virus-related human hepatocellular carcinoma. Clinical cancer research: an official journal of the American Association for Cancer Research. 2008; 14:2056-2064.

18. Safe S, Imanirad P, Sreevalsan S, Nair V, Jutooru I. Transcription factor $\mathrm{Sp} 1$, also known as specificity protein 1 as a therapeutic target. Expert opinion on therapeutic targets. 2014; 18:759-769.

19. Guan H, Cai J, Zhang N, Wu J, Yuan J, Li J, Li M. Sp1 is upregulated in human glioma, promotes MMP-2-mediated cell invasion and predicts poor clinical outcome. International journal of cancer Journal international du cancer. 2012; 130:593-601.

20. Jiang NY, Woda BA, Banner BF, Whalen GF, Dresser KA, Lu D. Sp1, a new biomarker that identifies a subset of aggressive pancreatic ductal adenocarcinoma. Cancer epidemiology, biomarkers \& prevention: a publication of the American Association for Cancer Research, cosponsored by the American Society of Preventive Oncology. 2008; 17:1648-1652.

21. Bedolla RG, Gong J, Prihoda TJ, Yeh IT, Thompson IM, Ghosh R, Kumar AP. Predictive value of Sp1/Sp3/FLIP signature for prostate cancer recurrence. PloS one. 2012; 7:e44917.

22. Maurer GD, Leupold JH, Schewe DM, Biller T, Kates RE, Hornung HM, Lau-Werner U, Post S, Allgayer H. Analysis of specific transcriptional regulators as early predictors of independent prognostic relevance in resected colorectal cancer. Clinical cancer research: an official journal of the American Association for Cancer Research. 2007; 13:1123-1132.

23. Wang L, Wei D, Huang S, Peng Z, Le X, Wu TT, Yao J, Ajani J, Xie K. Transcription factor Sp1 expression is a significant predictor of survival in human gastric cancer. Clinical cancer research: an official journal of the American Association for Cancer Research. 2003; 9:6371-6380.

24. Wang F, Ma YL, Zhang P, Shen TY, Shi CZ, Yang YZ, Moyer MP, Zhang HZ, Chen HQ, Liang Y, Qin HL. SP1 mediates the link between methylation of the tumour suppressor miR-149 and outcome in colorectal cancer. The Journal of pathology. 2013; 229:12-24.

25. Wright C, Angus B, Napier J, Wetherall M, Udagawa Y, Sainsbury JR, Johnston S, Carpenter F, Horne CH. Prognostic factors in breast cancer: immunohistochemical staining for SP1 and NCRC 11 related to survival, tumour epidermal growth factor receptor and oestrogen receptor status. The Journal of pathology. 1987; 153:325-331.

26. Hsu TI, Wang MC, Chen SY, Yeh YM, Su WC, Chang WC, Hung JJ. Sp1 expression regulates lung tumor progression. Oncogene. 2012; 31:3973-3988.

27. Kong LM, Liao CG, Chen L, Yang HS, Zhang SH, Zhang Z, Bian HJ, Xing JL, Chen ZN. Promoter hypomethylation up-regulates CD147 expression through increasing Sp1 binding and associates with poor prognosis in human hepatocellular carcinoma. Journal of cellular and molecular medicine. 2011; 15:1415-1428.

28. You X, Liu F, Zhang T, Lv N, Liu Q, Shan C, Du Y, Kong G, Wang T, Ye L, Zhang X. Hepatitis B virus X protein upregulates Lin28A/Lin28B through Sp-1/c-Myc to enhance the proliferation of hepatoma cells. Oncogene. $2014 ; 33: 449-460$. 
29. Jutooru I, Guthrie AS, Chadalapaka G, Pathi S, Kim K, Burghardt R, Jin UH, Safe S. Mechanism of action of phenethylisothiocyanate and other reactive oxygen species-inducing anticancer agents. Molecular and cellular biology. 2014; 34:2382-2395.

30. Hu QD, Chen W, Yan TL, Ma T, Chen CL, Liang C, Zhang Q, Xia XF, Liu H, Zhi X, Zheng XX, Bai XL, Yu XZ, Liang TB. NSC 74859 enhances doxorubicin cytotoxicity via inhibition of epithelial-mesenchymal transition in hepatocellular carcinoma cells. Cancer letters. 2012; 325:207-213.

31. Swarnalatha M, Singh AK, Kumar V. Promoter occupancy of MLL1 histone methyltransferase seems to specify the proliferative and apoptotic functions of E2F1 in a tumour microenvironment. J Cell Sci. 2013; 126:4636-4646.

32. Gao SB, Zheng QF, Xu B, Pan CB, Li KL, Zhao Y, Zheng QL, Lin X, Xue LX, Jin GH. EZH2 represses target genes through H3K27-dependent and H3K27-independent mechanisms in hepatocellular carcinoma. Molecular cancer research: MCR. 2014; 12:1388-1397.

33. Nair V, Pathi S, Jutooru I, Sreevalsan S, Basha R, Abdelrahim M, Samudio I, Safe S. Metformin inhibits pancreatic cancer cell and tumor growth and downregulates Sp transcription factors. Carcinogenesis. 2013; 34:2870-2879.

34. Abdelrahim M, Smith R 3rd, Burghardt R, Safe S. Role of $\mathrm{Sp}$ proteins in regulation of vascular endothelial growth factor expression and proliferation of pancreatic cancer cells. Cancer research. 2004; 64:6740-6749.

35. Chintharlapalli S, Papineni S, Abdelrahim M, Abudayyeh A, Jutooru I, Chadalapaka G, Wu F, MertensTalcott S, Vanderlaag K, Cho SD, Smith R 3rd, Safe S. Oncogenic microRNA-27a is a target for anticancer agent methyl 2-cyano-3, 11-dioxo-18beta-olean-1, 12-dien-30oate in colon cancer cells. International journal of cancer Journal international du cancer. 2009; 125:1965-1974.

36. Chadalapaka G, Jutooru I, Sreevalsan S, Pathi S, Kim K, Chen C, Crose L, Linardic C, Safe S. Inhibition of rhabdomyosarcoma cell and tumor growth by targeting specificity protein $(\mathrm{Sp})$ transcription factors. International journal of cancer Journal international du cancer. 2013; 132:795-806.

37. Jutooru I, Chadalapaka G, Abdelrahim M, Basha MR, Samudio I, Konopleva M, Andreeff M, Safe S. Methyl 2-cyano-3, 12-dioxooleana-1, 9-dien-28-oate decreases specificity protein transcription factors and inhibits pancreatic tumor growth: role of microRNA-27a. Molecular pharmacology. 2010; 78:226-236.

38. Jutooru I, Chadalapaka G, Lei P, Safe S. Inhibition of NFkappaB and pancreatic cancer cell and tumor growth by curcumin is dependent on specificity protein down-regulation. The Journal of biological chemistry. 2010; 285:25332-25344.

39. Sreevalsan S, Safe S. The cannabinoid WIN 55,212-2 decreases specificity protein transcription factors and the oncogenic cap protein eIF4E in colon cancer cells. Molecular cancer therapeutics. 2013; 12:2483-2493.

40. Chadalapaka G, Jutooru I, Safe S. Celastrol decreases specificity proteins (Sp) and fibroblast growth factor receptor-3 (FGFR3) in bladder cancer cells. Carcinogenesis. 2012; 33:886-894.

41. Lou Z, O'Reilly S, Liang H, Maher VM, Sleight SD, McCormick JJ. Down-regulation of overexpressed sp1 protein in human fibrosarcoma cell lines inhibits tumor formation. Cancer research. 2005; 65:1007-1017.

42. Abdelrahim $\mathrm{M}$, Baker $\mathrm{CH}$, Abbruzzese JL, Sheikh-Hamad D, Liu S, Cho SD, Yoon K, Safe S. Regulation of vascular endothelial growth factor receptor-1 expression by specificity proteins 1,3 , and 4 in pancreatic cancer cells. Cancer research. 2007; 67:3286-3294.

43. Chadalapaka G, Jutooru I, Chintharlapalli S, Papineni S, Smith R 3rd, Li X, Safe S. Curcumin decreases specificity protein expression in bladder cancer cells. Cancer research. 2008; 68:5345-5354.

44. Chen HP, Shieh JJ, Chang CC, Chen TT, Lin JT, $\mathrm{Wu} \mathrm{MS}$, Lin JH, Wu CY. Metformin decreases hepatocellular carcinoma risk in a dose-dependent manner: population-based and in vitro studies. Gut. 2013; 62:606-615.

45. Zhang H, Gao C, Fang L, Zhao HC, Yao SK. Metformin and reduced risk of hepatocellular carcinoma in diabetic patients: a meta-analysis. Scandinavian journal of gastroenterology. 2013; 48:78-87.

46. Zheng L, Yang W, Wu F, Wang C, Yu L, Tang L, Qiu B, Li Y, Guo L, Wu M, Feng G, Zou D, Wang H. Prognostic significance of AMPK activation and therapeutic effects of metformin in hepatocellular carcinoma. Clinical cancer research: an official journal of the American Association for Cancer Research. 2013; 19:5372-5380.

47. Pernicova I, Korbonits M. Metformin - mode of action and clinical implications for diabetes and cancer. Nature reviews Endocrinology. 2014; 10:143-156.

48. Kupershmidt I, Su QJ, Grewal A, Sundaresh S, Halperin I, Flynn J, Shekar M, Wang H, Park J, Cui W, Wall GD, Wisotzkey R, Alag S, Akhtari S, Ronaghi M. Ontology-based meta-analysis of global collections of high-throughput public data. PloS one. 2010; 5. 